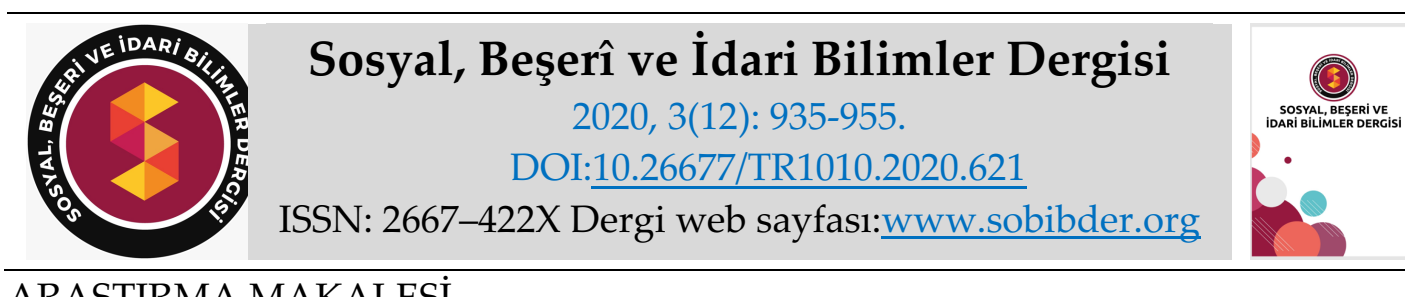

ARAȘTIRMA MAKALESI

\title{
Otel Çalışanı ve Misafirinin Covid 19 Pandemi Kurallarına Uyumu: Antalya ve Muğla Karşılaştırması
}

Prof. Dr. Orhan BATMAN, Sakarya Uygulamalı Bilimler Üniversitesi, Turizm Fakültesi, Sakarya, e-posta: obatman@subu.edu.tr

ORCID: https://orcid.org/0000-0001-7186-7064

Dr. Öğr. Üyesi İsmail BİLGİÇLİ, Sakarya Uygulamalı Bilimler Üniversitesi, Karasu Meslek Yüksekokulu, Sakarya, e-posta: bilgicli@subu.edu.tr

ORCID: https://orcid.org/0000-0003-1697-032X

Öğr. Gör. Dr. Recep YILDIRGAN, Sakarya Uygulamalı Bilimler Üniversitesi, Sapanca Turizm Meslek Yüksekokulu, Sakarya, e-posta: recepy@subu.edu.tr

ORCID: https://orcid.org/0000-0002-9887-3883

Öz

Bu çalışma, Covid-19 salgını sürecinde otel işletmelerinde alınan önlemlerin ve uygulanan kuralların misafirler ve çalışanlar tarafından uyumlarını araştırmak amacıyla gerçekleştirilmiştir. Pandemi sürecinde sağlıklı turizm kriterleri doğrultusunda gerekli önlemleri alıp, buna uygun standartları belirleyen otel işletmeleri uzun bir serinin ardından yeniden misafir kabul etmeye başlamıştır. Bu çalışmanın saha araştırmaları Antalya ve Muğla' da faaliyet gösteren beş yıldızlı 2 otel işletmesinde yapılmıştır. Haziran-Ağustos 2020 tarihlerinde araştırmacılar tarafından bizzat konaklama yapılan bu işletmelerde gözlem, katılımcı gözlem ve görüşme yöntemlerine dayalı veri toplama işlemleri gerçekleştirilmiştir. Elde edilen veriler betimsel analize tabi tutulmuştur. Bu doğrultuda her iki otelden 7 'şer departmana yöneticisi ile derinlemesine görüşmeler yapılarak konu iki yönlü olarak analiz edilmiştir. Elde edilen bulgulara göre, Antalya ve Muğla'daki otel işletmelerinde personelin alınan pandemi kurallarına uyumu yüksek düzeydedir. Ancak misafirlerin bu kurallara uyumu incelendiğinde, Antalya'da son derece düşük bir uyum söz konusu iken, Muğla'da çok daha yüksek bir uyum dikkat çekmektedir.

Anahtar Kelimeler: Pandemi, Covid-19, Otel İşletmeleri, Sağlıklı Turizm.

Makale Gönderme Tarihi: 13.08 .2020

Makale Kabul Tarihi: 02.12 .2020

Önerilen Atıf:

Batman, O., Bilgiçli, İ. ve Yıldırgan, R. (2020). Otel Çalışanı ve Misafirinin Covid 19 Pandemi Kurallarına Uyumu: Antalya ve Muğla Karşılaştırması, Sosyal, Beşeri ve İdari Bilimler Dergisi, 3(12): 935-955.

(C) 2020 Sosyal, Beşerî ve İdari Bilimler Dergisi. 


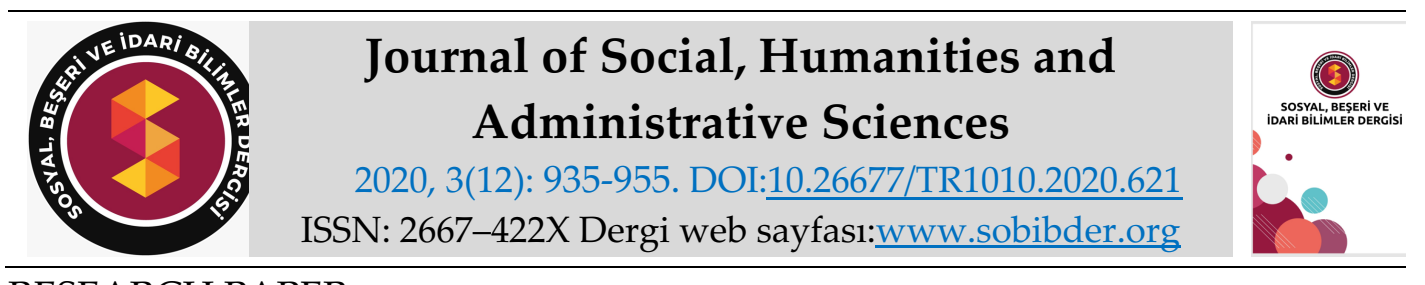

$\underline{\text { RESEARCH PAPER }}$

\title{
Hotel Employee and Guest Compliance with Covid 19 Pandemic Rules: Comparison of Antalya and Muğla
}

Prof. Dr. Orhan BATMAN, Sakarya University of Applied Sciences, Faculty of Tourism, Sakarya, e-mail: obatman@subu.edu.tr

ORCID: https://orcid.org/0000-0001-7186-7064

Assistant Prof. Dr. İsmail BİLGİçL̇, Sakarya University of Applied Sciences, Karasu Vocational School, Sakarya, e-mail: bilgicli@subu.edu.tr

ORCID: https://orcid.org/0000-0003-1697-032X

Dr. Recep YILDIRGAN, Sakarya University of Applied Sciences, Sapanca Turizm Vocational School, Sakarya, e-mail: recepy@subu.edu.tr

ORCID: https://orcid.org/0000-0002-9887-3883

\begin{abstract}
This study was carried out in order to investigate the compliance of the measures taken and the rules applied in hotel enterprises during the covid-19 outbreak by guests and employees. Hotel businesses that took the necessary measures in line with the Healthy Tourism criteria during the pandemic process and set the appropriate standards have started to accept guests again after a long series. Field studies of this study were conducted in two five-star hotel enterprises operating in Antalya and Muğla. Data collection based on observation, participant observation and interview methods were carried out in these establishments where the researchers personally accommodated between June-August 2020. The obtained data were subjected to descriptive analysis. In this direction, in-depth interviews were made with 7 department managers from both hotels and the issue was analyzed in two directions. According to the findings obtained, the compliance of the personnel with the pandemic rules taken in hotel enterprises in Antalya and Muğla is at a high level. However, when the compliance of the guests with these rules is examined, while there is an extremely low compliance in Antalya, a much higher harmony draws attention in Muğla.
\end{abstract}

Keywords: Covid-19, Coronavirus, Tourism, Yacht Tourism.

Received: 13.08 .2020

Accepted: 02.12.2020

Suggested Citation:

Batman, O., Bilgiçli, İ. and Yıldırgan, R. (2020). Hotel Employee and Guest Compliance with Covid 19 Pandemic Rules: Comparison of Antalya and Muğla, Journal of Social, Humanities and Administrative Sciences, 3(12): 935-955.

(C) 2020 Sosyal, Beşerî ve İdari Bilimler Dergisi. 


\section{Gíriş}

Dünya genelini etkisi altına alan Covid-19 salgınının olumsuz yansımalarının en fazla görülmekte olduğu sektörlerin başında konaklama sektörü gelmektedir. Seyahat ve uçuş yasakları, karantina uygulamaları, sokağa çıkma kısıtlamaları, ülkelerin sınırlarını dış dünyaya kapatmaları gibi önlemlerin yanında, insanların pandemiye ilişkin kaygıları, turizmde hem arz hem de talep yönlü düşüşler yaşanmasına neden olmuştur (Işın, 2020). Turizm endüstrisinin en önemli ayaklarından biri olan konaklama sektörü bu süreçte ciddi sorunlarla karşı karşıya kalmıştır. Gerek faaliyetlerini sürdürebilmek gerek istihdamın sürekliliğini sağlayabilmek ve çalışanlarının iş güvenliğini ve sağlığını koruyabilmek ve gerekse misafirlerinin güvenli ve sağlıklı bir ortamda konaklama yapabilmelerini sağlamak noktasında otel işletmelerinin yoğunlaşması gereken birçok sorun olduğu bilinmektedir. Akademik yazında da henüz çok yeni olan bu problem, pek çok araştırmanın güncel konusunu oluşturmaktadır.

Bu araştırmada ise Sağlıklı Turizm Sertifikasyonu doğrultusunda geliştirilen kriterleri uygulayan otel işletmelerinde alınan önlem ve kurallara misafirlerin ve çalışanların uyum ve tutumları araştırılmıştır. Bu doğrultuda araştırma, Antalya ve Muğla bölgelerinde seçilmiş iki ayrı otel işletmesinde farklı tarihlerde konaklayan misafirlerin ve çalışanların pandemi önlemleri kapsamında uyguladıkları kurallara uyumunu kıyaslayacak şekilde tasarlanmıştır. Öncelikle, alan yazın bakımından henüz yeni olan bu konu, literatürde detaylı olarak taranmış, araştırmanın kapsamı ve içeriği bu doğrultuda şekillendirilmiştir.

\section{KORONAVIRÜS (COVID-19)}

Çin'in Hubei eyaleti Wuhan kentinde 2019 yılı Aralık ayında yeni bir koronavirüsün neden olduğu salgın bir hastalık oluşmuştur (Zheng Ying vd., 2020: 259). Şiddetli akut solunum sendromu olarak adlandırılan koronavirüs 2 salgın haline dönüşerek, Çin'e yayılmaya başlamıştır. Dünya Sağlık Örgütü (WHO) koronavirüs nedeniyle oluşan bu hastalığı resmi olarak Coronavirus hastalığı (Covid-19) olarak isimlendirmiştir (Zi Yue Zu vd., 2020: 3).

Coronavirus'ler (CoV), soğuk algınlığından Orta Doğu Solunum Sendromu (MERS-CoV) ve Ağır Akut Solunum Sendromu (Severe Acute Respiratory Syndrome, SARS-CoV) gibi daha ciddi hastalıklara kadar çeşitli hastalıklara neden olan büyük bir virüs ailesidir. Yeni koronavirüs, daha önce insanlarda tanımlanmamıştır. Bu yeni virüs, soğuk algınlığı, SARS ve MERS gibi virüsleri de içeren bir virüs ailesi olan koronavirüs olup geçici olarak "2019-nCoV." olarak adlandırılmıştır. 12 Şubat 2020 itibariyle COVID-19 olarak güncellenmiştir. Coronavirus'lar zoonotik olup, hayvanlardan bulaşarak insanlarda hastalık yapabilir. Detaylı araştırmalar sonucunda, SARS-CoV'un misk kedilerinden, MERS-CoV'un ise tek hörgüçlü develerden insanlara bulaştı̆̆ı ortaya çıkmıştır (Acar, 2020: 9).

Koronavirüs (Covid-19) salgına neden olan küresel bir salgın hastalıktır. Nisan ayının sonlarında dünya genelinde 185 ülkede hastalar enfekte olmuş ve 210.000 'den fazla insanın ölümü ile sonuçlanmıştır. Vaka sayısı ise üç milyonu aşmış durumdadır. Covid-19 salgını Çin'e başlamıştır, ancak Çin dışındaki ülkelere hızla ulaşarak Mart ayının ortalarında Çin'deki vaka ve ölüm sayılarının üstüne katlanarak çıkmıştır (Clerkin vd., 2020: 1648). Aralık ayında Çin'de oluşan salgın ile ilgili olarak virüsün tanımlanması ve izolasyonunun sonrasında (2019-NCOV)2 adı verilmiştir. Daha sonra resmi olarak şiddetli akut sendromu olarak adlandırılmıştır. Dünya sağlık örgütü tarafından solunum sendromu coronavirus2 olarak isimlendirilen hastalık 2020 yılı Ocak ayında SARS-COV-2 olduğu ve halk sağlığı açısından acil durum ilan edilmesine neden olmuştur (Zheng Ying vd., 2020: 259). 
2020 yılı Mart-Nisan-Mayıs gibi yaklaşık üç ay içerisinde vaka sayılarındaki hızlı ve önlenemez yükseliş koronavirüsü dünyanın tamamını tehdit eden salgın hastalık pozisyonuna getirmiştir (Karaoğlu, 2020: 55). Dünya genelinde 2020 yılı Mart ayında etkili olan, önceleri "Epidemi" daha sonra ise dünya geneline seyahatler ile hızlı bir şekilde yayılmasıyla "Pandemi" olarak ilan edilen bir hastalıktır (Cucinotta ve Vanelli, 2020: 157).

Koronavirüs (Covid-19) salgınına ilişkin dünya genelinde ülkelerin yayınladığı durum raporları virüsün küresel olarak açtığı tahribatın seviyesini göstermektedir. Tüm dünya halklarının sağlığını tehdit eden bu salgına karşı dünya sağlık örgütü talimatlar yayınlayarak kırmızı alarma geçilmesini sağlamıştır. Koronavirüs (Covid-19) ile ilgili yakın tarihli bilimsel çalışmalarda belirtilen en temel nokta taşıyıcı insanların yaptıkları seyahatlerin virüsün yayılmasında etkili olduğudur (Wilson ve Chen, 2020: 2). Dünya genelinde yüksek vaka ve ölüm sayılarına rağmen Türkiye vaka ve ölüm sayıları ile oranları açısından iyi durumda olan ülkeler arasında görülmektedir (Kutlu, 2020: 341). Koronavirüs (Covid-19) ile ilgili bilim insanları yoğun bir şekilde yayınlar yapmaya başlamışlardır. Bu çalışmalarda;

Ahmad vd., (2020) çalışmalarında Çin'de oluşan ve dünyayı hızlı bir şekilde saran virüs ile ilgili istatistiki bilgiler vererek, Çin'e yakın olan komşu ülkelerin (Pakistan, Hindistan vb.) coğrafi dezavantajlarının olduğu, Çin ile ticari ilişkilerin yüksek risk oluşturduğunu belirtmişlerdir. Bogoch vd., (2020) tarafından yapılan çalışmada virüsün etki alanının genişlemesinin oluşturabileceği muhtemel sorunlar değerlendirilmiştir. Du vd., (2020) tarafından yapılan çalışmada koronavirüsün ilk oluşum aylarında ortaya çıktığı Wuhan'dan Çin'in 369 şehrine yayılma olasılığını tahmin etmek üzerine değerlendirmelerde bulunmuşlardır.

Chiodini (2020) çalışmasında dünya sağlık örgütünün koronavirüs ile ilgili yaptı̆̆g tanımlar ve muhtemel korunma yöntemleri hakkında bilgiler sunulmakta, dünya genelinde ülkeler arası yapılabilecek iş birliklerinin önemi belirtilmektedir. Columbus vd., (2020) çalışmalarında 2020 yılının Şubat ayına kadar olan sürede koronavirüsün dünyada yayılabileceği alanlar ve küresel olarak oluşturduğu tehditler vurgulanmaktadır. Mahase (2020) çalışmasında dünya sağlık örgütü ve dünya turizm örgütüne ait resmi web sitelerinde yayınlanan raporlar ve yayınlar incelenmiştir. Çalışmada koronavirüsün ortaya çıktığı andan itibaren dünya genelinde sağlık malzemelerinin (maske, eldiven vb.) talebinin arttığı, talebe bağlı olarak fiyatlarında ciddi artışlar gösterdiği belirtilmektedir.

Quilty vd., (2020) tarafından yapılan çalışmada ülke içinde ve ülkelerarası havaalanlarında giriş ve çıkışlarda koronavirüsün kontrol altına alınabilmesinde termal kamera taramalarının son derece önemli olduğu belirtilmesine rağmen, koronavirüs bulaşmış yolcuların \%46'sının (\%95 güven aralığı ile 36-58 yaş arası yapılan çalışma) tespit edilemeyeceği belirtilmektedir. Rodriguez vd., (2020) çalışmalarında Brezilya'nın tarihi geçmişinde birçok salgın hastalıkla uğraşmak zorunda kaldığını, ülkede onaylanan ilk koronavirüs vakasının 640 milyon nüfusa yaklaşan diğer Latin Amerika ülkelerine uyarı niteliğinde değerlendirilmesi gerektiği belirtilmektedir.

\section{KORONAVİÜS COVID-19 ve TURİM İLIŞKİSi}

Koronavirüs (Covid-19) salgını sonrasında dünyada yaşanan gelişmeler doğrultusunda, uzmanların önemli bir kısmı dünyanın değişeceğini, "yeni bir dünya" veya "farklı bir şey" oluşacağı gibi ifadeler kullanarak endüstri alanları ile ilgili farklı yorumlar yapmışlardır (Budak ve Korkmaz, 2020: 75). Uluslararası bir çalışma alanı olan turizm endüstrisinin "yeni bir dünya" veya "farklı bir şey" gibi oluşumlardan etkilenmeden varlığını sürdürmesi mümkün değildir. Turizm endüstrisinde insandan insana etkileşimin çok yüksek olması, emek-yoğun istihdamın yaygın olması bilinen bir gerçektir. Bunun yanında böylesi bir salgın sürecinde insan 
hareketlerinin kısıtlanması ve seyahatlerin engellenmesi nedeniyle turizm endüstrisi yaşanan bu süreçten en fazla etkilenen alanların başında gelmiştir.

Turizm faaliyetlerinin yön değiştirmesine neden olan önemli bir diğer kriz unsuru ise salgın hastalıklarıdır (Kiper vd., 2020: 2). Destinasyonlarda salgın gibi nedenlerden güvenlik eksikliğinin oluşması özellikle tercih edilme ile ilgili endişeleri ortaya çıkarmaktadır (Avraham, 2016: 42). Küresel turizm hareketlerinin azalması, turizm gelirlerinde azalmaya ve ekonomik kayıplara neden olmaktadır. Salgın nedeniyle küresel seyahat hareketlerinin \%80 oranında azalması turizm ekonomisini etkilemiştir (Erol, 2020: 220).

Koronavirüs sürecinde ve sonrasında en çok etkilenen endüstrilerden olan turizm, istihdam kayıpları yaşayarak, turizm işletmelerinin zor şartlarda açılmaya gayret göstereceği bir ortamda yaşamlarını sürdürmeye çalışmaktadırlar. Koronavirüsün yol açtığı salgın ortamında İspanya, Fransa ve İtalya gibi turizmde öne çıkan ülkelerin, müdahale ve tedbir noktasında geç kalmaları, yavaş ve etkisiz müdahalelerde bulunmaları salgının daha da yayılmasında etkili olmuşlardır. Küresel olarak yaşanan bu süreç ve sorun küresel etkiler göstermektedir (Çobanoğlu, 2020: 42).

Salgın sürecinde ulaşıma getirilen seyahat kısıtlamalarının kaldırılması ulaştırma işletmelerinde iktisadi açıdan kısmi bir hareketlilik yaratsa da beklentileri karşılayacak yeterliliğe ulaşamayacaktır (Günay vd., 2020: 28). Koronavirüs salgını bireysel yaşantıları kısıtlayarak dünya genelinde ekonomik krizi tetikleyici bir gelişme yaratmıştır. Covid-19'un turizm açısından tespit edilebilir somut etkilerinin olmasının yanında turizm işletmelerini, çalışanlarını ve turizmden beklentisi olan tüm destinasyonları olumsuz etkilemiştir (Bahar ve İlal, 2020: 129).

Dünyada ülkelerin salgına karşı uyguladıkları tedbirlerden giriş-çıkış yasaklamaları, karantina tedbirleri, kalabalık katılımlı organizasyonların iptal edilmesi ve seyahatlerin kısıtlanması turizm endüstrisini ve ilgili tüm bileşenlerini doğrudan etkilemiştir (Strielkowski, 2020: 1; Acar, 2020: 7). Salgından korunmanın en etkili ve kesin yolu, insanlar arasında mesafenin korunmasıdır. Mesafe korumanın etkisinin uygulanmasında turizm işletmelerinin olduğu kadar yerli ve yabancı turistlerinde tedbirlere riayet etmeleri önemlidir. Turizm endüstrisinde faaliyet gösteren konaklama, yiyecek-içecek, ulaştırma ve diğer turizm işletmelerinin dikkat edeceği ve uygulayacağı adımlar ve önlemlerin yanında müşterilerinde salgın tedbirlerine uyması ve özen göstermesi gereklidir. Alınan önlemlerin temel amacı sağlığın güvence altına alınmasıdır (Atay, 2020: 170).

Turizmden ekonomik olarak fayda sağlayan ülkelerden en önemlilerinden olan ülkelerden birisi Türkiye'dir. Tüm dünyanın etkilendiği bir salgından global ticaret düzeninde Türkiye'nin etkilenmemesi mümkün değildir. Türkiye için turist sayısının turizm gelirleri dikkate alınarak hesaplandığında turist sayısında \%10'luk bir azalma turizm gelirlerine de \%10 yansıyabilmektedir (Demir, 2020: 15). Literatürde incelenen çalışmaların ortak noktası salgın hastalıkların özellikle hizmet üretimi gerçekleştiren tüm ülkeler ve özellikle turizm işletmelerini etkilemiştir.

\section{YÖNTEM}

Araştırma nitel olarak tasarlanmıştır. Veri toplama yönteminde gözlem, katılımcı gözlem ve derinlemesine görüşme teknikleri birlikte kullanılmıştır. Katılımcı gözlem tekniğinde araştırmacı, çalıştı̆̆ konuya ilişkin kültür ya da alt kültürlerin içine girmeye ve bir parçası olmaya çalışır (Yıldırım ve Şimşek, 2013: 201). Bu araştırmayı yürüten yazarlar tıpkı bir turist gibi diğer misafirlerle aynı ortamda konaklama yapmış, aynı fiziksel ortamlarda bulunarak onlarla aynı ürün ve hizmetleri kullanmıştır. Öte yandan, işletme yöneticileri ile görüşmeler yapılarak, 
onların konu hakkındaki düşünceleri saptanmaya çalışılmıştır. Burada yarı yapılandırılmış görüşme tekniği tercih edilmiştir. Bu veri toplama tekniğinde önceden detaylı bir şekilde oluşturulmuş ve belli bir akışa göre sıraya konmuş açık uçlu sorular sorulmaktadır (Patton, 1987: 112).

Antalya'daki saha araştırması 06.07.2020 - 09.07.2020 tarihleri arasında 5 yıldızlı bir otelde, Muğla'daki saha araştırması 29.07.2020 - 05.08.2020 tarihleri arasında 5 yıldızlı bir otelde araştırmacılar tarafından konaklama yapılarak veriler toplanmıştır. Antalya' daki otelde 4 gün boyunca, Muğla'daki otelde 8 gün boyunca oteldeki tıpkı bir misafir gibi tüm ürün ve hizmetler kullanılarak gözlemler yapılmıştır. Ayrıca her iki otelin çeşitli departmanlarında yönetici olarak görev yapan 7'şer kişi ile derinlemesine görüşmeler yapılmıştır.

\section{Gözlemlere İlişkin Bulguları}

Araştırma kapsamında öncelikle nitel veri toplama yöntemlerinden biri olan gözlem metodu ile veri toplanmıştır. Burada özellikle katılımcı gözlem tekniği tercih edilmiş olup, araştırmacılardan birincisi bizzat Antalya bölgesindeki konaklama işletmesinde 4 gün konaklayarak misafirler ile aynı ortamda bulunmuş ve detaylı gözlem yapma olanağ sağlamıştır. Bu bağlamda 06-09 Temmuz 2020 tarihleri arasında Antalya bölgesinde bulunan beş yıldız bir otelde veriler elde edilmiştir. İkinci araştırmacı 29 Temmuz ve 5 Ağustos tarihleri arasında Muğla bölgesinde bulunan beş yıldızlı bir otelde 8 gün boyunca konaklayarak müşteriler ile aynı hizmetten yararlanmış ve gözlem yapma olanağına sahip olmuştur. Elde edilen bilgiler ışığında aşağıdaki sonuçlara ulaşılmıştır.

\section{Konaklama İşletmelerinin Tanıtımı}

Araştırma alanı olarak kullanılan ilk otel işletmesi, Antalya bölgesinde yer alan, ultra her şey dâhil hizmet veren, 549 odalı 5 yıldız bir işletmedir. Covid-19 salgını sonrası birçok işletme gibi faaliyetlerine ara vermek zorunda kalan işletme, daha sonra Sağlıklı Turizm Sertifikası alarak, 15 Haziran 2020 tarihinde kapılarını misafirlerine yeniden açmıştır. Toplam 135 kriterden oluşan Sağlıklı Turizm Sertifikasyonu otelin tüm fiziksel birimlerinde uyulması gereken pek çok kuralları içermektedir. Ayda iki kez uluslararası bir denetim firması tarafından denetlenen işletme, bu kuralları hem otelin tüm alanlarında, hem de çalışanlar ve misafirler nezdinde takip etmektedir. Otelde gözlem yapılan 4 gün süresince ortalama doluluk; birinci gün 700, ikinci gün 729, üçüncü gün 760 ve dördüncü gün 760 kişi olarak gerçekleşmiştir. Covid-19 sürecinde otellerin yarı kapasite çalışma zorunluluğu dikkate alınırsa bu doluluk düzeyleri makul olarak değerlendirilebilir. İşletme, aldığı tedbirler kapsamında bu süreçte, spa, fitness center ve mini club birimlerini kapalı tutmayı tercih etmiştir.

Araştırma kapsamında yer alan ikinci otel işletmesi Muğla bölgesinde bulunan ve her şey dâhil hizmet veren, 500 odalı beş yıldızlı bir işletmedir. Koronavirüs salgınının dünya genelinde ve Türkiye' de etkilediği hizmet sektörlerinde faaliyet gösteren işletmelerden birisi olmuş ve faaliyetlerine ara vermiş ve müşteri kabulü yapmamıştır. Covid-19 sürecinin ilerleyen aşamalarında salgın tedbirlerinin azaltılması ve turizm faaliyetlerine başlanabilmesi amacıyla tesislerin sağlık yeterliliklerini gösteren sağlıklı turizm sertifikası alınarak 1 Temmuz 2020 tarihinden itibaren müşteri kabulüne başlanmıştır. Uluslararası denetim firmasının ayda iki kez denetiminden geçen tesis sağlık kurallarının uygulanması ve denetlenmesinde tüm personel, yönetim ve sağlık bakanlığı ile uyumlu bir çalışma 
göstermektedir. Otelin gözlem yapılan sürelerde doluluk oranları 29 Temmuz günü 250 kişi, 30 Temmuz günü 350 kişi, 31 Temmuz günü 470 kişi, 1 Ağustos günü 500 kişi, 2 Ağustos günü 525 kişi, 3 Ağustos günü 550 kişi, 4 Ağustos günü 500 kişi, olarak gerçekleşmiştir. 1 Ağustostan itibaren müşteri sayılarındaki artışın nedeni olarak İngiltere' den gelen turistlerin turizme katılımları olarak gözlemlenmiştir. Otel müşteri kapasitesi olan 1000 kişilik turist kapasitesinin yarısı ile çalışmaktadır. Doluluk oranları, tesis kapasitesi ve sahip olduğu coğrafi alan büyüklüğü $(250.000 \mathrm{~m} 2)$ dikkate alındığında salgın hastalıkla mücadelede oldukça uygun bir ortama sahip olunduğu görülmektedir. Tesiste SPA, kuaför ve benzeri hizmetlerin gösterildiği alanlara giriş sınırlı tutulmakta ve rezervasyon sistemi ile hizmet verilmektedir. Fitness center ve mini club faaliyetleri ile diğer eğlence organizasyonlarının açık alanda yapılması için düzenlemeler yapılmış ve katılımcıların ön rezervasyon ile faaliyetlere katılımı sağlanarak sosyal mesafe düzenlemeleri yapılmıştır.

\section{Otele Giriş}

Antalya'daki işletme, otele giriş anından itibaren Sağlıklı Turizm Sertifikası gereği getirilen tüm kuralları uygulamaktadır. Güvenlik girişinde misafirlerin ateşi ölçülerek otele kabulü yapılmaktadır. Loby girişinde ise görüntülü bir ateş ölçer cihaz ile konuklar karşılanmakta, hemen orada el dezenfektanı ve maskeye ulaşım sağlanabilmektedir. Otelin tüm birimlerinde misafirlerin uyması gereken kurallar yönlendirme tabelaları ya da duvar panoları ile belirtilmiştir. Personelin başta maske kullanımı olmak üzere tüm kurallara hassasiyetle uyduğu gözlemlenmiştir. Ancak misafirlere tercih hakkı tanınmaktadır. Yani isteyen misafir maske takmakta, istemeyen takmamaktadır. Buna karşın otel yetkililerinden alınan bilgiye göre; otelin açılış tarihinden itibaren 13 bin maske dağıtılmıştır. Aynı şekilde ulaşılabilir her yerde el dezenfektanı bulundurulmaktadır. Gözlemlerimize göre misafirlerin bu el dezenfektanlarına çok ilgi göstermediği tespit edilse de yine otel yönetiminden alınan bilgiye göre dezenfektan tüketimi de oldukça yüksek boyutta gerçekleşmektedir.

Muğla'da faaliyet gösteren otel işletmesine girişte tüm misafirlerin ateşi ölçülmekte, maskesi olmayan ve maske takmak isteyen misafirler için maske verilmektedir. Tüm personelin maske taktığı ve kurallara uygun bir maske kullanımının olduğu görülmüştür. Sosyal mesafe ile ilgili uyarı levhaları, bariyerler ve yönlendiriciler otel girişinden itibaren tüm alanlarda, asansör ve katlarda otel içi genel kullanım alanlarında mevcuttur. Otelin girişinden itibaren tüm ulaşılabilir alanlarda el dezenfektanları bulunmaktadır. Misafirlere eşyalarının taşınmasında bellboyların talep etmeleri halinde yardımcı olacağı resepsiyon görevlisi tarafından belirtilmektedir. Resepsiyon görevlisi oda kartlarının dezenfekte edildiğini belirterek misafirlerin istemesi halinde tatil süresince istenildiğinde resepsiyonda dezenfekte edileceğini belirtmişlerdir. Misafirlerin personel ile iletişimini azaltmak amacıyla oluşturulan Whatsapp ve çağrı merkezi aracılığı ile müşterilerin personele bilgi aktarımı ve alımı gerçekleştirilmektedir. Otel içi ulaşımda kullanılan golf arabalarında aile dişında kişilerin kullanımında sınırlı sayıda kişi uygulaması yapılmaktadır.

\section{Odalar}

Antalya'daki otel işletmesi, katlarda ve odalarda gereken tüm önlemleri almış görülmektedir. Asansörlerde el dezenfektanı ve uyarı levhaları nizami bir şekilde yerleştirilmiştir. Aileler dışında birbirine yapancı kişilerin asansöre aynı anda 2 kişiden fazla binmemeleri konusunda uyarılar dikkat çekmektedir. Odalarda ise pandemi öncesi duruma göre bazı farklı uygulamalar söz konudur. Çay ve kahve için plastik bardak kullanımına 
geçilmiş, banyolara el dezenfektanı konulmuş, TV kumandası şeffaf kılıf içine yerleştirilmiştir. Boşalan odalar en az 12 saat pencereleri açık şekilde havalandırılmaktadır. Bunun öncesinde dezenfeksiyon ve ULV işlemleri uygulanmakta, temizliği biten odanın yastık, çarşaf ve pikeleri 12 saat boyunca odada bulundurulmamaktadır. Odalar normal rutin doğrultusunda 2 günde bir temizlenmektedir.

Muğla ilinde gözlemlenen otelin odalarında ilk göze çarpan uygulama yatak örtüleri ve minder gibi eşyaların kaldırılmış olduğudur. Kat hizmetleri görevlilerinin tümünde eldiven, maske ve önlük kullanıldığı görülmüştür. Görüşülen kat görevlisi odaların temizliği yapılırken havalandırıldığını ve misafir girmeden önce en az 12 saat boyunca boş bırakıldığını (Varsa virüslerin yaşam sürelerinin bitmesi açısından) belirtmişlerdir. Kat görevlileri oda mobilyalarının yüksek buhar ile ekstra temizlendiğini belirtmişler, havlu ve nevresim takımlarının hijyenik olarak odalara aktarımının sağlandığını belirtmişlerdir. Misafirlerin odalarında her gün temizlik istemesi durumunda resepsiyona bilgi vererek, Whatsapp veya çağrı merkezi aracılığıyla iletmeleri halinde istekleri karşılanmaktadır. Otel odalarında el dezenfektanı ve beş adetlik paketler halinde maskenin her gün odalara koyulduğu gözlemlenmiştir.

\section{Restoran ve Barlar}

Antalya'da gözlemlenen otel işletmesinde Covid-19 kapsamında alınan önlemlerin uygulanmasında en çok sıkıntı yaşanan birimler yiyecek içecek alanlarıdır. Otel işletmesi bu birimlerde tüm önlemleri almasına, açık büfe sistemini düzenlemesine, sosyal mesafe ve el dezenfeksiyonu gibi kuralları belirlemesine rağmen; misafirlerin bu kurallara çok büyük oranda uymadıkları gözlemlenmiştir. Bunda açık büfenin dizayn edilme biçiminin de büyük payı olduğu düşünülmektedir. Büfe, restoranın tam ortasına dikdörtgen biçiminde konuşlandırılmış, şeffaf paravanlarla misafirlerin yemeklere teması önlenmiş, servis sınırlı sayıdaki mutfak personeli tarafından gerçekleştirilmektedir. Yemek saatlerindeki aşırı yoğunluk, sosyal mesafe kurallarına uyulmamasını beraberinde getirmektedir. Oysa büfe, restoranın farklı bölgelerine, yemek gruplarını ayırarak yerleştirilerek, misafirlerin aşırı yoğunluğu azaltılabilir, böylece sosyal mesafe daha rahat sağlanabilir. Bunun dişında misafirler maske kullanımı ve sosyal mesafe konusunda hiçbir şekilde uyarılamamaktadır. Misafirler ise bu konuda son derece duyarsız ve özgür hareket etmektedir.

Muğla'da gözlemlenen otel işletmesinde restoran ve barlarda müşterilerin fiziksel temas ve mesafelerinde rahatlık söz konusudur. Bunun nedeni olarak tesis odalarının tam kapasite dolu olmaması gösterilebilir. Restoran girişlerinde görevli maskesiz gelenleri uyarmakta maskesiz girişin yasak olduğu belirtilerek müşterilere maske vererek restorana girmeleri sağlanmaktadır. Restoran içerisinde yiyecek-içecek alımında müşterilerin kesinlikle maske ile dolaşmaları için uyarılar yapılarak maskesiz olanların maske takmaları istenmektedir. Restoran ve barlarda masa ve sandalyeler arasında sosyal mesafe düzenlemesi ve uyarıcı işaretlemeler yeterli ve belirgin şekilde oluşturulmuştur. Kolay ulaşılabilir alanlarda el dezenfektanı ve maske kutuları bulunmakta, eğer müşteri isterse veya maskesiz geldiyse buradan maske teminini gerçekleştirilmektedir. Restoran ve barlarda misafirler self servis hizmet yerine el temasının azaltılması adına personel tarafından hizmet verilmektedir. Restoranda tuz karabiber ve şeker gibi malzemeler tek kullanımlık paketler halinde servis edilmektedir. Restoranlarda masalarda kumaş masa örtüleri ve peçetelerin kullanılmadiğ 1 görülmüştür. Çatal, kaşık ve bıçak takımları paketlenmiş şekilde masalarda bulunmaktadır. Restoranlarda müşterilerin terk ettiği masa sadece bu iş için hazır bekleyen personel tarafından temizlenip dezenfekte edilmekte ve 10-15 dakika yeni müşteri kabul edilmemesi 
için masa etrafı şerit bantlarla kapatılarak sürenin geçmesi beklenmektedir. Görevliler yakınlaşma gözlemlediği zaman nazikçe uyarılarda bulunmaktadırlar. Barlarda tek kullanımlık bardakların kullanıldığı görülmüştür. Müşterilerin kendilerine ait cam bardakları ile servis talep etmeleri halinde aynı bardaklar ile servis yapılabilmektedir. Restoran ve barlarda yerli ve yabancı misafirlerin kurallara dikkat etmede özen gösterdikleri tespit edilmiştir.

\section{Havuz, Aquapark ve Plaj}

Antalya'da çalışma yapılan otelde bu alanlar gün boyu gözleme tabi tutularak, yoğunluğun hangi saatlerde ve bölgelerde gerçekleştiği tespit edilmeye çalışılmıştır. Havuz, aquapark ve plajın kullanımı esnasında sosyal mesafeye dikkat edildiği söylenebilir. Şezlonglar sosyal mesafeye uygun biçimde yerleştirilmiş, havuz içinde insanların birbirlerine olan mesafesi kurallara uygun biçimde olduğu gözlenmiştir.

Muğla'da bulunan otel işletmesinde şezlongların sosyal mesafe kurallarına uygun düzenlendiği, düzenli olarak temizlendiği ve müşterilerin terk etmesinin ardından derhal dezenfekte edildiği gözlenmiştir. Havuzların zaman zaman görevliler tarafından su alınarak ölçümlerin yapıldığ gözlenmiştir. Otel içinde farklı yerlerde bulunan tüm havuzlarda kolay görünebilecek şekilde havuz su ölçümü kimyasal değerlerinin sonuçlarının gösterildiği bilgilendirme levhaları mevcuttur. Otelin sahip olduğu coğrafi alan büyüklüğü ile orantılı havuz alanının genişliğini kullanarak misafirlerin sosyal mesafeye uygun hizmet alması için düzenlemelerin yapıldı̆̆ı görülmüştür.

\section{Loby}

Antalya'da bulunan otelin loby'sinde günün hiçbir saatinde bir yoğunlaşma gözlemlenmemiş, hatta genel anlamda boş olduğu dikkat çekmiştir.

Muğla'da bulunan otelin loby'sinde yer alan koltuk sayılarının azaltıldığı kişiler arasında sosyal mesafenin korunduğu görülmektedir. Loby'de misafirler arasında aile dişında kişilerin yakın temasının olmaması için gerekli tedbirlerin alındığı görülmektedir. Misafirler arasında temasın yakınlaşması gibi bir durum hem yerli ve hem de yabancı misafirleri açısından gözlemlenmemiştir. Görevliler yakınlaşma gözlemlediği zaman nazikçe uyarılarda bulunmaktadırlar.

\section{Asansör Kullanımı}

Antalya'da gözlem yapılan otelde asansörler, uyarılara uyularak kullanılmaktadır. Aile bireylerinin birlikte kullanımı dışında genel olarak asansörlerde yoğunluk gözlemlenmemiştir.

Muğla'da gözlem yapılan otelde asansör gibi genel kullanım alanında sadece ailelerin toplu bir şekilde asansör kullanması ve sosyal mesafe için farklı dillerde uyarı yazılarının yanında tüm asansör girişlerinde ayrıca personel görevlendirilmiş ve personel tarafından farklı dillerde uyarı yapılması sağlanmıştır. 


\section{Animasyon Aktiviteleri}

Antalya'da gözlem yapılan otelde sosyal mesafeyi olumsuz etkileyecek eğlence ve aktivitelere yer verilmemektedir. Diğer bireysel spor aktiviteleri, canlı müzik gibi showlar uygulanmaktadır. Animasyon aktivitelerinin tamamı açık alanlarda gerçekleştirildiği için herhangi bir olumsuz durum gözlenmemiştir. Pandemi kuralları doğrultusunda maske kullanımı, en önemli önlemlerden biridir. Misafirlere maske takma konusunda bir zorunluluk getirilmemekle birlikte, tavsiye edilmektedir. Ancak otelde konaklayan misafirlerin hemen hemen hiçbiri maske takmamaktadır. Buna karşın personelin tamamının maske kullandığı ve kurallara tam olarak uyduğu görülmüştür. Tesisin birçok noktasında el dezenfektanı bulunmaktadır. Otel yetkililerinden alınan bilgiye göre bu dezenfektanların tüketiminin yüksek olduğu tespit edilmiştir.

Muğla'da bulunan turizm tesisinde yapılan gözlemde yetişkin ve çocuklara yönelik etkinliklerde belirli kapasite ve sosyal mesafe kurallarına riayet edilecek faaliyetler programda yer almaktadır. Etkinlilerin kişilerin yakınlaşmasını (Köpük partileri, havuz eğlenceleri, su topu vb.) sağlamayacak eğlenceler olarak düzenlendiği görülmektedir. Ayrıca bu etkinliklere katılım için kapasiteye uygunluğu sağlama ve kontrol etme açısından ön rezervasyon yapmak gerekmektedir. Aktivitelerin tümünün açık alanda yapılacak etkinlikler olmasına dikkat edilmektedir.

\section{Personelin Çalışma Ortamı Gözlemleri}

Antalya'daki otel işletmesinde çalışanların pandemi kurallarına tam olarak uyum sağladığ 1 söylenebilir. Her ne kadar çok sıcak bir iklimde çalışmak zorunda kalsalar da maske kullanımı konusunda taviz verilmemektedir. Antalya ilinde sadece kapalı mekânlarda ve toplu ulaşım araçlarında maske kullanımı zorunlu olmasına rağmen, otel personelinin otelin açı ve kapalı tüm alanlarında maske kullanması dikkat çekicidir. Personel lojmanları kurallar dâhilinde düzenlenmiştir. Personel yemekhanesi de geçici bir süre için, otelin alakart restoranlarından birine taşınarak, sosyal mesafenin uygulanabilirliği artırılmıştır. Ancak maske ve sosyal mesafeye uygun davranmayan misafirler personel tarafindan uyarılmamaktadır. Bu konu ile ilgili görüşülen personel, misafiri uyarma noktasında amirinden herhangi bir talimat almadığını belirtmiştir.

Otelin içinde yer alan mağazalar ve diğer çalışan personel ile yapılan görüşmelerde tüm personele hizmet içi eğitimler verildiği tespit edilmiştir. Pandemi ile ilgili sağlık kuruluşundan gelen bulaşıcı hastalıklar konusunda uzman bir doktorun eğitim verdiği, kendilerinde sağlıkları ile ilgili bir değişiklik gözlemlemeleri durumunda derhal sağlıklarını takip etmek için doktora görüneceklerini belirten bilgilendirme yapıldığ 1 söylenmiştir. Personelin salgın süreci ve değişen durumlar ile ilgili rutin şekilde bilgilendirildiği maske, koruyucu kıyafet ve temizlik konularında titiz davranmaları konusunda sürekli takip ve uyarı yapıldığı belirtilmiştir. Personel yemekhanesi ve diğer kullanım alanlarında çalışanların departman ayrımı ile belirli saatlerde hizmet alınmasının sağlandığı gözlenmiştir. Personel yemekhanelerinde masa ve sandalye düzenlemeleri sosyal mesafeye uygundur ve dezenfeksiyon işlemleri müşteri mekânları gibi aynı titizlikle yapılmaktadır. 


\section{Görüşmeye İlişkin Bulgular}

Tablo 1'de Antalya ve Muğla'da faaliyet gösteren otellerde yönetici olarak çalışan araştırma sorularına verdikleri cevaplar ile katkı sağlayan katılımcıların demografik bilgileri yer almaktadır. Bu bilgilere göre yöneticilerin eğitim seviyelerinin en düşük ön lisans düzeyinde olması turizm işletmeleri adına sevindiricidir. Katılımcı yöneticilerin on bir tanesinin Lisans mezunu, iki tanesinin Yüksek lisans mezunu olduğu görülmektedir. Katılımcı yöneticilerin yaş aralığının 33-54 gibi bir yaş seviyesinde olması, çok yaşlı olmayan bir grubun yönetimde olduğu sonucunu bize göstermektedir. Yöneticilerin tecrübe olarak en düşük on yıllık tecrübeye sahip olması turizm endüstrisi adına sevindirici ve umut vericidir. Diğer yöneticilerin de on yıldan daha üst seviyelerde otuz iki yıla varacak değişik seviyelerde tecrübeye sahip olması yöneticilerin turizm deneyimlerinin yeterli olduğu sonucuna varılmasını sağlayabilir. Demografik yönetici verilerine göre katılımcıların büyük çoğunluğu (11 kişi) erkek, üç adet katılımcı ise kadındır.

Tablo 1 Antalya/Muğla Otel Yöneticilerinin Demografik Bilgileri

\begin{tabular}{|c|c|c|c|c|c|}
\hline $\begin{array}{l}\text { Antalya/Muğla Otel } \\
\text { Yöneticileri }\end{array}$ & 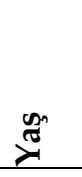 & 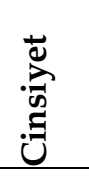 & 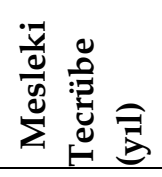 & 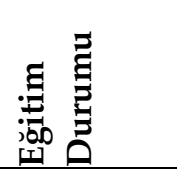 & 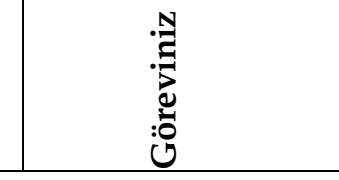 \\
\hline Antalya Yönetici 1 & 43 & $\mathrm{E}$ & 25 & Lisans & İKY Müdürü \\
\hline Muğla Yönetici 1 & 53 & $\mathrm{E}$ & 22 & Lisans & F/B Müdürü \\
\hline Antalya Yönetici 2 & 44 & $\mathrm{E}$ & 26 & Lisans & F/B Müdürü \\
\hline Muğla Yönetici 2 & 33 & K & 10 & Lisans & Kalite Müdürü \\
\hline Antalya Yönetici 3 & 54 & E & 10 & Önlisans & Güvenlik Müdürü \\
\hline Muğla Yönetici 3 & 45 & E & 20 & Y. Lisans & Oper. Müdürü \\
\hline Antalya Yönetici 4 & 42 & $\mathrm{E}$ & 21 & Lisans & Kalite Müdürü \\
\hline Muğla Yönetici 4 & 48 & $\mathrm{E}$ & 21 & Y. Lisans & Halkla İliş. Müdürü \\
\hline Antalya Yönetici 5 & 52 & E & 32 & Lisans & Genel Müdür \\
\hline Muğla Yönetici 5 & 44 & $\mathrm{E}$ & 15 & Lisans & Güvenlik Müdürü \\
\hline Antalya Yönetici 6 & 38 & $\mathrm{~K}$ & 20 & Lisans & Kat Hiz. Müdürü \\
\hline Muğla Yönetici 6 & 47 & $\mathrm{E}$ & 15 & Lisans & Önbüro Müdürü \\
\hline Antalya Yönetici 7 & 39 & K & 20 & Lisans & Misafir İliş. Müdürü \\
\hline Muğla Yönetici 7 & 38 & $\mathrm{E}$ & 15 & Lisans & İKY Müdürü \\
\hline
\end{tabular}

Araştırma kapsamında görüşme yapılan otel yöneticilerinden elde edilen verilerin çözümlemesinde betimsel analiz yöntemi kullanılmıştır. Bu doğrultuda katılımcıların görüşleri doğrudan alıntı şeklinde değerlendirilmiş, odak noktalar belirlenerek, yorumlanmıştır. Antalya'daki otel yöneticileri, AOY1....... AOY7 şeklinde, Muğla'daki otel yöneticileri de MOY1 ...... MOY7 şeklinde kodlanmıştır. 
Tablo 2. Misafirlerin Genel Anlamda Pandemi Konusunda Alınan Kurallara Uyup Uymadığına İlişkin Otel Yöneticilerinin Görüşleri

\begin{tabular}{|c|c|}
\hline Görüş (Doğrudan alıntılar) & Odak Noktalar \\
\hline $\begin{array}{l}\text { AOY1:" ...Genel olarak \%90 önlemlere uyulmuyor...." } \\
\text { MOY1:"...Genel olarak uyuyorlar. \%80..." } \\
\text { AOY2:"....\%90 kurallara uyulmuyor...." } \\
\text { MOY2:"...\%90 oraninda uyuluyor..." } \\
\text { AOY3:"...Hayır. \%80'i uymuyor..." } \\
\text { MOY3:"...\%80 oranında..." } \\
\text { AOY4:"...\%90 uyulmuyor...." } \\
\text { MOY4:"...Evet. \%85..." } \\
\text { AOY5:" ...\%20'si uyuyor. Sosyo-ekonomik düzeyi yüksek olanlar } \\
\text { uyuyor, geri kalanlarda kurallara uyum çok zayıf...." } \\
\text { MOY5:"...\%95 oranında kurallara uyuyorlar..." } \\
\text { AOY6:"...\%80'i uyum sağlamış durumdadır..." } \\
\text { MOY6:"...Genel olarak uyumlu, \%90..." } \\
\text { AOY7:"...\%30'u uyuyor, \%70'i ise uymuyor..." } \\
\text { MOY7:"...Genel olarak uyuyorlar, \%95..." }\end{array}$ & $\begin{array}{l}\text { Büyük bir çoğunluk } \\
\text { kurallara } \\
\text { uymamaktadır. } \\
\text { (Antalya) } \\
\text { Büyük bir çoğunluk } \\
\text { kurallara uymaktadır. } \\
\text { (Muğla) }\end{array}$ \\
\hline
\end{tabular}

Tablo 3. Kurallara Uymayan Misafirlere Herhangi Bir Yaptırım Uygulanıp Uygulanmadığına İlişkin Yönetici Görüşleri

\begin{tabular}{|c|c|}
\hline Görüş (Doğrudan alıntılar) & Odak Noktalar \\
\hline 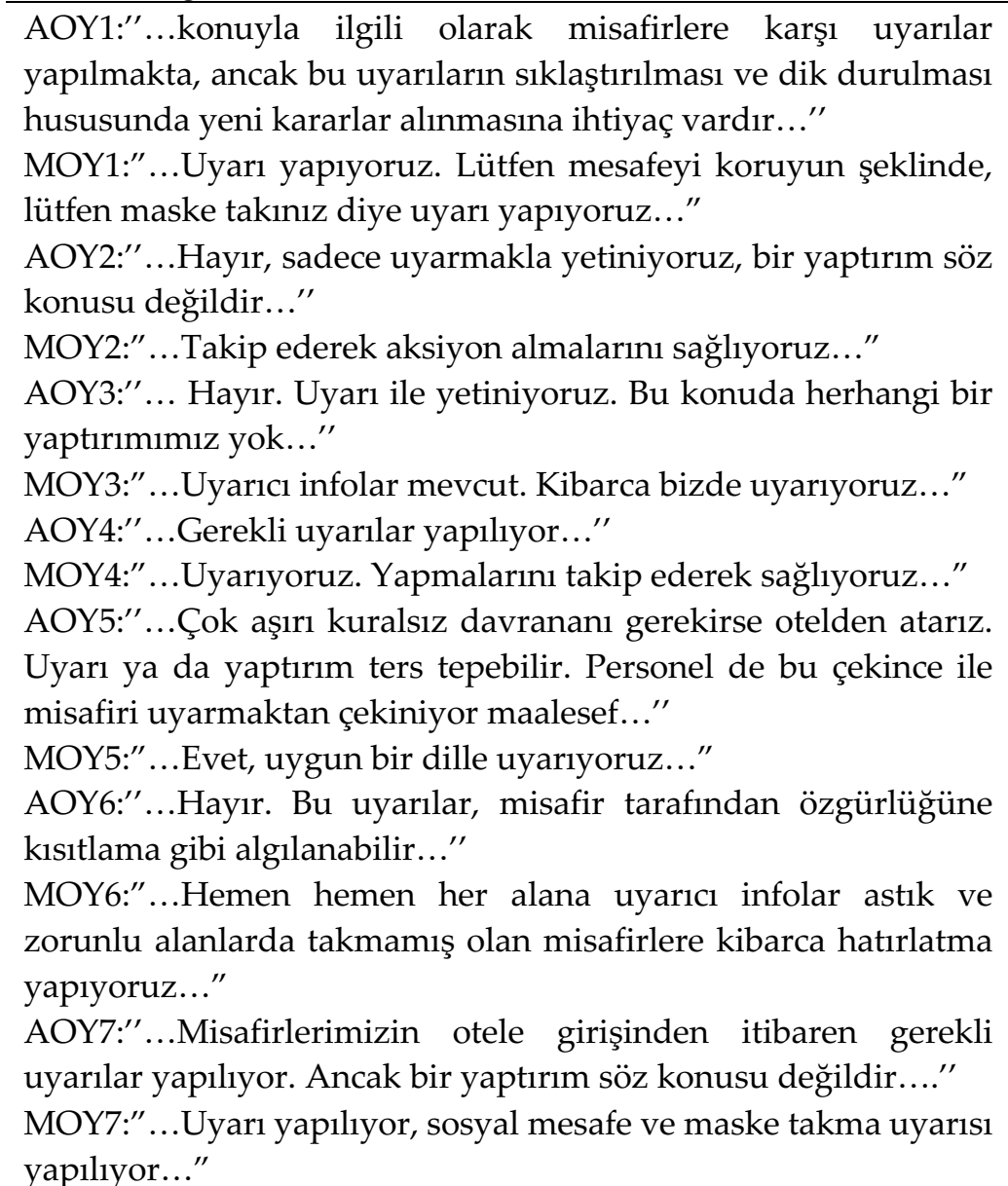 & $\begin{array}{l}\text { Misafirlerin nazikçe } \\
\text { uyarılması ve takip } \\
\text { edilerek yapmalarının } \\
\text { saplanması } \\
\text { (Muğla) } \\
\text { Misafirler uyarılmakta } \\
\text { ancak herhangi bir } \\
\text { yaptırım söz konusu } \\
\text { değildir. } \\
\text { (Antalya) }\end{array}$ \\
\hline
\end{tabular}


Muğla otel yöneticilerinin birinci soru olan "misafirlerin genel anlamda pandemi konusunda alınan kurallara uyup uymadığı" konusunda verdikleri cevaplarda misafirlerin yüksek oranda uyumlu oldukları belirtilmiştir. Verilen cevaplara göre misafirlerin yaklaşı $\% 85$ 'inin kurallara tam olarak uyduğu belirtilmiştir.

Antalya'daki otel işletmesinde yöneticilerin büyük çoğunluğu misafirlerin pandemi kurallarına uymadığı görüşündedir. Özellikle çeşitli departmanların yöneticilerine göre alınan pandemi önlemlerine uyum konusunda gereken hassasiyeti göstermemektedir. Otelin gereken tüm önlemleri almasına rağmen bilhassa maske kullanımı ve sosyal mesafeye dikkat etme konularında kurallara uymadıkları belirtilmiştir.

Muğla'daki otel yöneticilerinin "Kurallara uymayan misafirlere karşı herhangi bir yaptırımınız oluyor mu? Nasıl?" sorusuna verdikleri cevaplar incelendiğinde yüksek oranda kurallara uyulduğunu belirten yöneticiler, kalan azınlıkta olsa diğer misafirlerin kurallara uyması konusunda nazikçe uyarıldığını ve misafirlerin uyarıları yerine getirmelerinin sağlanması için takip ettiklerini belirtmeleri önemli bir odak noktasıdır.

Antalya'daki otelde yöneticiler misafirlerin kurallar konusunda uyarıldığını ancak bir yaptırımın mümkün olmadığını belirtmektedir. Misafirlerle bire bir aynı ortamda bulunan personelin ise kurallara uymayan misafirleri uyarmaya çekindiği dile getirilmiştir.

Tablo 4. Personelin Alınan Pandemi Önlemlerine Uyumu ve Tutumuna İlişkin Yönetici Görüşleri

\begin{tabular}{|c|c|}
\hline Görüş (Doğrudan alıntılar) & Odak Noktalar \\
\hline $\begin{array}{l}\text { AOY1:" ...Personel, maske ve kişisel koruyucu kullanımı konusunda } \\
\text { misafirlerden çok daha duyarlı davranmaktadır..." } \\
\text { MOY1:"...Personel çok dikkatli..." } \\
\text { AOY2:"...Personel kurallara uymaya özen gösteriyor. Herhangi bir } \\
\text { sıkıntıda işletmenin zorda kalacağını çok iyi biliyorlar..." } \\
\text { MOY2:"...Personel genel manada dikkatli, sürece kurallara uyum } \\
\text { sağlamaya çalışıorlar..." } \\
\text { AOY3:" ...Personelimiz kural ve önlemlere tamamen uymakta, } \\
\text { maske takma konusunda zorluk yaşamakla birlikte takmaktadır..." } \\
\text { MOY3:"...\%100 uyum gösteriyorlar..." } \\
\text { AOY4:"...Personel kurallara uyuyor. Havalar çok sıcak olduğundan } \\
\text { zorlanmalarına rağmen genelde kurallara uyumlular..." } \\
\text { MOY4:"...Tüm personel çok titiz, olumlu tutum sergiliyorlar..." } \\
\text { AOY5:"...\%99 tam bir uyum söz konusudur..." } \\
\text { MOY5:"...\%100 uyuyorlar, uymak zorundalar..." } \\
\text { AOY6:"..Personel mutlak surette kurallara uyum gösteriyor..." } \\
\text { MOY6:"...Tüm personel kurallara uyuyor..." } \\
\text { AOY7:"...Havaların sıcak olmasından dolayı maske kullanımında } \\
\text { zorlanıyorlar..." } \\
\text { MOY7:"...Maske ve siperlik kullanımı sicak havalarda çalışanlar için } \\
\text { zorlayıcı olsa da genel olarak herkes özen gösteriyor. Personel için } \\
\text { ayrılan dezenfektan ünitelerinin çok sık bittiğini ve tekrar } \\
\text { doldurulduğunu fark ettim ..." }\end{array}$ & $\begin{array}{l}\text { Personel olumlu, } \\
\text { yapıcı ve uyumlu } \\
\text { tutum sergiliyor. } \\
\text { (Muğla) } \\
\text { Personelin kurallara } \\
\text { uyumu son derece } \\
\text { yüksek düzeydedir. } \\
\text { (Antalya) }\end{array}$ \\
\hline
\end{tabular}

Tablo 4'te Muğla' da faaliyet gösteren otel işletmesinin yöneticilerine sorulan "Personelin alınan pandemi önlemlerine yönelik uyumu ve tutumunu nasıl değerlendirirsiniz? 
Sorusunda verilen cevapların incelenerek analiz edilmesi sonucu oluşan odak noktası işletme personelinin pandemi kurallarına uyduğu, olumlu ve yapıcı bir tutum sergiledikleri yönündedir.

Antalya'daki personelin kurallara uyumu tamdır. Zorlayıcı koşullara rağmen personel kurallara uymaya özen göstermektedir. Özellikle maske kullanımı konusunda yöneticiler de maske takarak tüm çalışanlara örnek teşkil etmektedir.

Tablo 5. Pandemi Sürecinde Yöneticilerin İşle İlgili En çok Zorlandı̆̆ı Konulara İlişkin Görüşleri

\begin{tabular}{|c|c|}
\hline Görüş (Doğrudan alıntılar) & Odak Noktalar \\
\hline 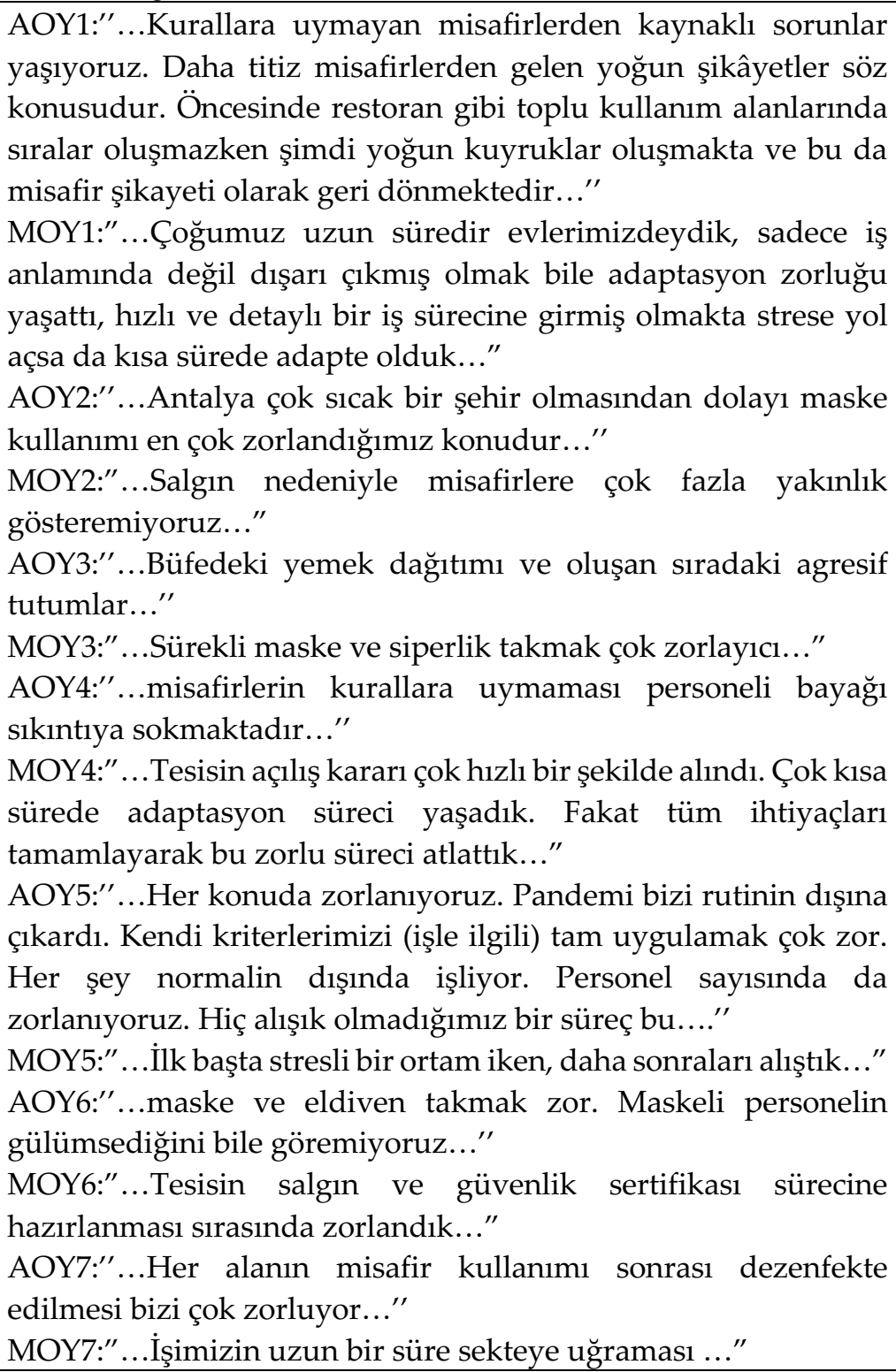 & $\begin{array}{l}\text { Güvenlik sertifikası alma } \\
\text { aşamasında yaşanan } \\
\text { stres, uzun ve yorucu } \\
\text { süreç. } \\
\text { (Muğla) } \\
\text { Rutin dışı işlemler, yeni } \\
\text { iş yükleri, misafirlerin } \\
\text { direnç göstermesi. } \\
\text { (Antalya) }\end{array}$ \\
\hline
\end{tabular}

Muğla'daki otel yöneticilerinin dördüncü soru olan "Pandemi sürecinde yöneticilerin işle ilgili en çok zorlandığınız konular nelerdir" sorusuna verdikleri cevapların incelenmesi sonucunda tespit edilen odak noktaları tesisin güvenlik sertifikası alma sürecinde yöneticilerin stresli, uzun ve yorucu bir çalışma ortamından geçtikleri yönündedir. 
Antalya'daki otel yöneticileri, böyle bir süreçle ilk kez karşılaşılmasından dolayı çok zorlandıklarını belirtmişlerdir. Daha önceki alışılmış düzenin dışında pek çok işlem ve davranış biçiminin hem kendilerini hem de çalışanları zorladığını dile getirmektedirler.

Tablo 6. Misafirlerin Kurallara Uyumu Konusunda En Çok Sıkıntı Yaşanan Departmanlara İlişkin Görüşleri

\begin{tabular}{|c|c|}
\hline Görüş (Doğrudan alıntılar) & Odak Noktalar \\
\hline 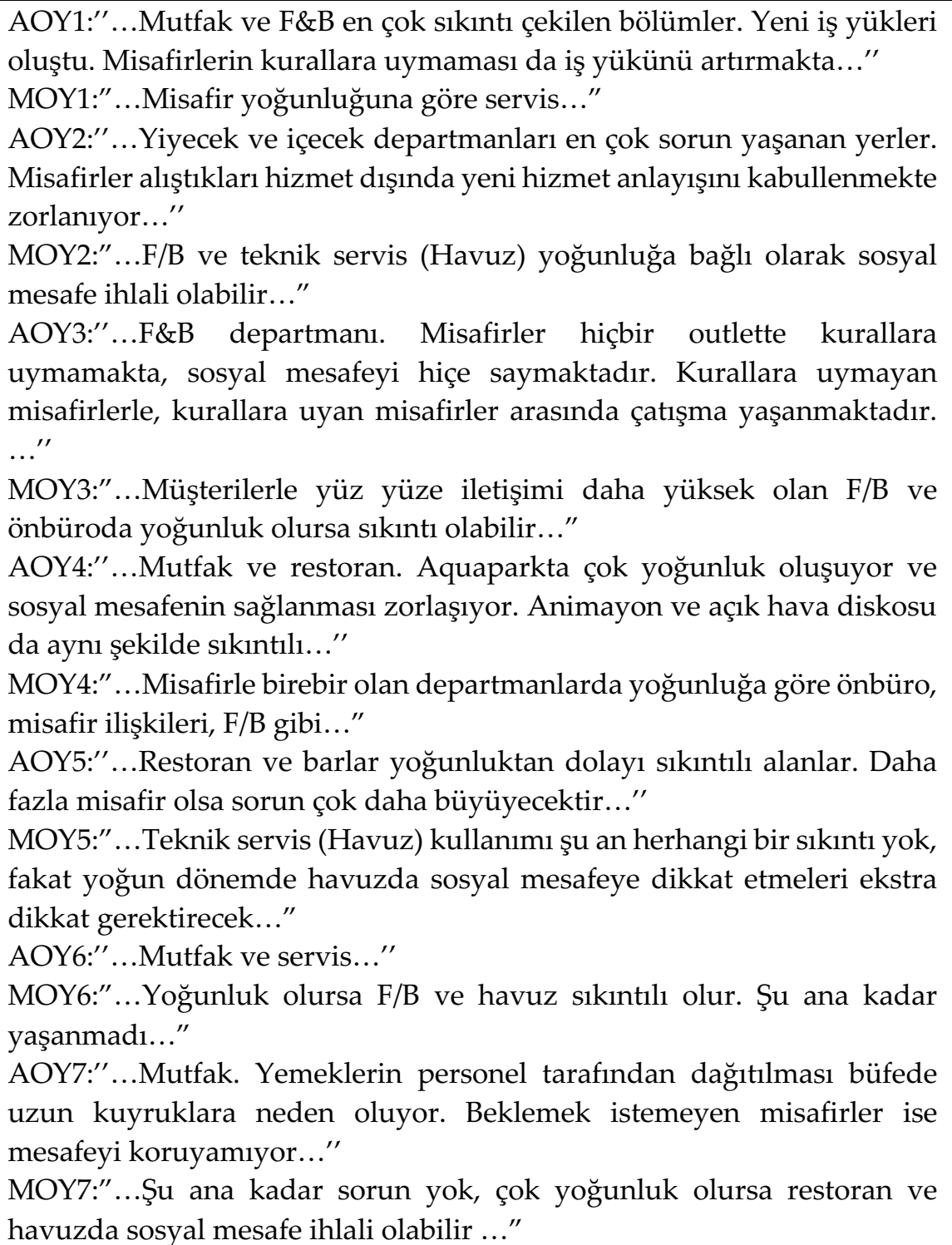 & $\begin{array}{l}\text { Yarı kapasite } \\
\text { çalışıldığı için şu } \\
\text { ana kadar } \\
\text { yoğunluğun } \\
\text { yaşanmadığı, } \\
\text { tam kapasite } \\
\text { çalışılsa, } \\
\text { yoğunluğun F/B, } \\
\text { Havuz gibi } \\
\text { alanlarda sıkıntı } \\
\text { yaratabileceği... } \\
\text { (Muğla) } \\
\text { Yiyecek içecek } \\
\text { departmanı } \\
\text { (Antalya) }\end{array}$ \\
\hline
\end{tabular}

Muğla otel yöneticilerinin beşinci soru olan "Sizce misafirlerin kurallara uyumu konusunda en çok hangi departmanlarda sıkıntı çekilmektedir? Sizce neden? Sorusu ile ilgili verdikleri cevaplardan oluşan Tablo 6 incelendiğinde oluşan odak noktası; tesisin yarı kapasite çalışmasının pandemi kurallarının misafirler tarafından uygulanmasında sorun yaşanmadığ 1 fakat tesis tam kapasite çalışsa $\mathrm{F} / \mathrm{B}$ ve havuz gibi alanlarda kural ihlalleri yaşanabileceği yönündedir.

Antalya'daki otelde yöneticiler en çok sıkıntı yaşanan departman olarak Yiyecek-içecek departmanını belirtmişlerdir. Özellikle ana restoranda oluşan yemek sıraları, sosyal 
mesafenin göz ardı edilmesine neden olmaktadır.

Tablo 7 Pandemi Sürecinde Bir Konaklama İşletmesinde Çalışıyor Olmaktan Dolayı Tedirgin Olup Olmadıklarına İlişkin Yönetici Görüşleri

\begin{tabular}{|c|c|}
\hline Görüș (Doğrudan alıntılar) & Odak Noktalar \\
\hline 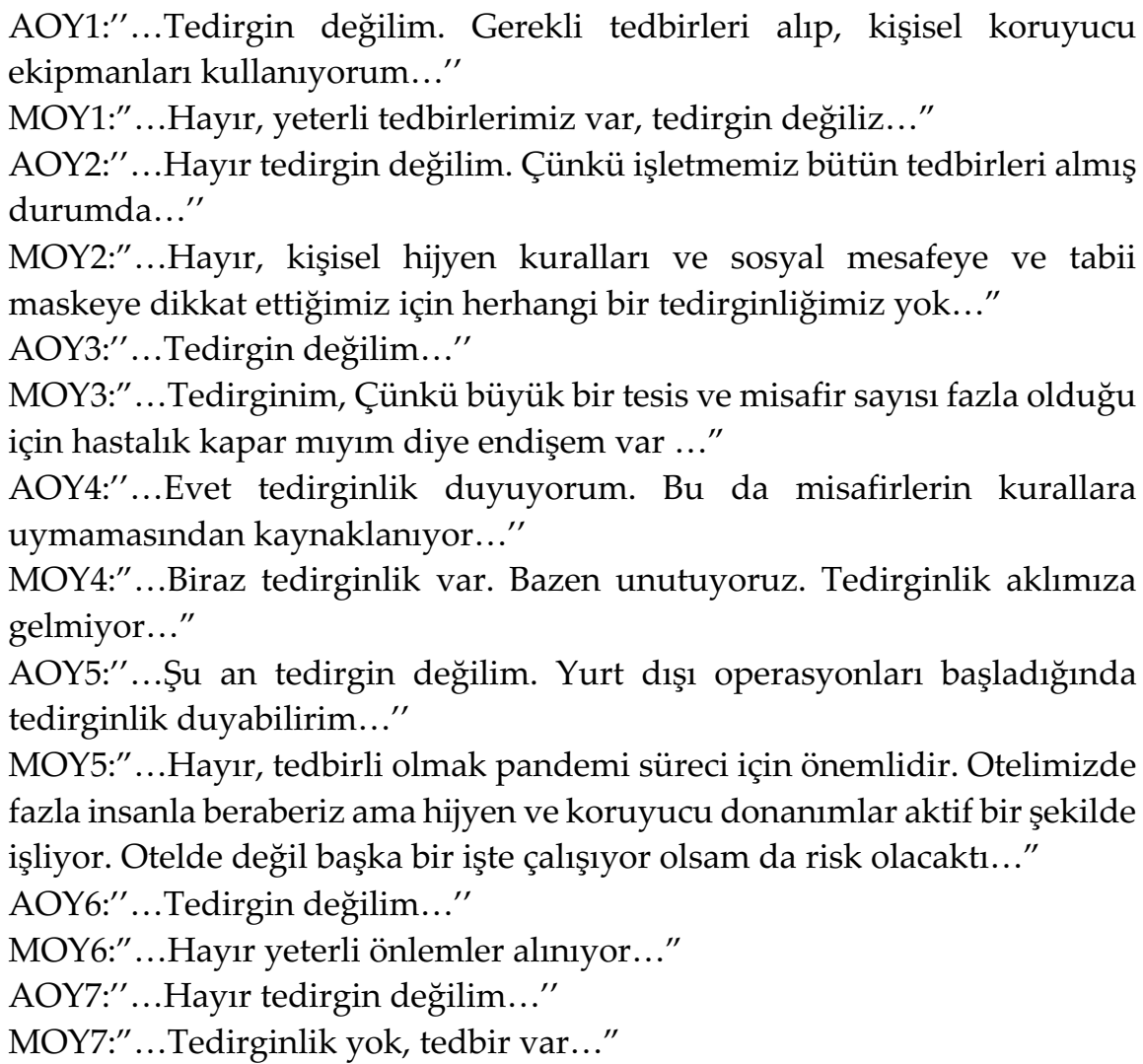 & $\begin{array}{l}\text { İnsani } \\
\text { tedirginliklerin } \\
\text { oluştuğu fakat } \\
\text { tedbirlere } \\
\text { güvenin } \\
\text { tedirginliği } \\
\text { azaltması. } \\
\text { (Muğla) }\end{array}$ \\
\hline
\end{tabular}

Tablo 7'de Muğla otel yöneticilerine sorulan "Pandemi sürecinde bir konaklama işletmesinde çalışıyor olmaktan dolayı tedirgin misiniz? Neden?" sorusu ile ilgili verilen cevaplar değerlendirildiğinde ortaya çıkan odak noktaları yöneticilerin insani tedirginlikler yaşadıklarını fakat alınan tedbirlerin tedirginliklerini azalttığı ve iş ortamının yoğunluğundan tedirginliklerini unutturduğu şeklindedir.

Antalya'daki yöneticiler pandemi sürecinde bir otel işletmesinde çalışıyor olmaktan dolayı tedirginlik hissetmediklerini belirtmektedirler. Kendi kişisel korunma tedbirlerinin yanında otelin almış olduğu tedbirler de onlara kendilerini rahat hissettirmektedir.

"Pandemi kuralları altında hizmet vermenin zorluklarına ilişkin yönetici görüşleri" ile ilgili sorulan yedinci soruya ilişkin Muğla'da faaliyet gösteren otel işletmesinin yöneticilerinin verdikleri cevapların Tablo 8 'de belirtilen analizinden tespit edilen odak noktaları; iklim koşullarının tedbir kurallarından maske ve siperlik kullanımında zorluk oluşturması yönündedir.

Antalya'daki otel yöneticilerine göre, pandeminin kendisi başlı başına zor bir süreç. Yeni kurallar dâhilinde çalışmak, alışılmışın dışında bir hizmet anlayışı geliştirmek, bunun yanında sıcak hava koşulları altında bu sürece uyum sağlamak ciddi anlamda zorluklar getirmektedir. 
Tablo 8. Pandemi Kuralları Altında Hizmet Vermenin Zorluklarına İlişkin Yönetici Görüşleri

\begin{tabular}{|c|c|}
\hline Görüş (Doğrudan alıntılar) & $\begin{array}{l}\text { Odak } \\
\text { Noktalar }\end{array}$ \\
\hline 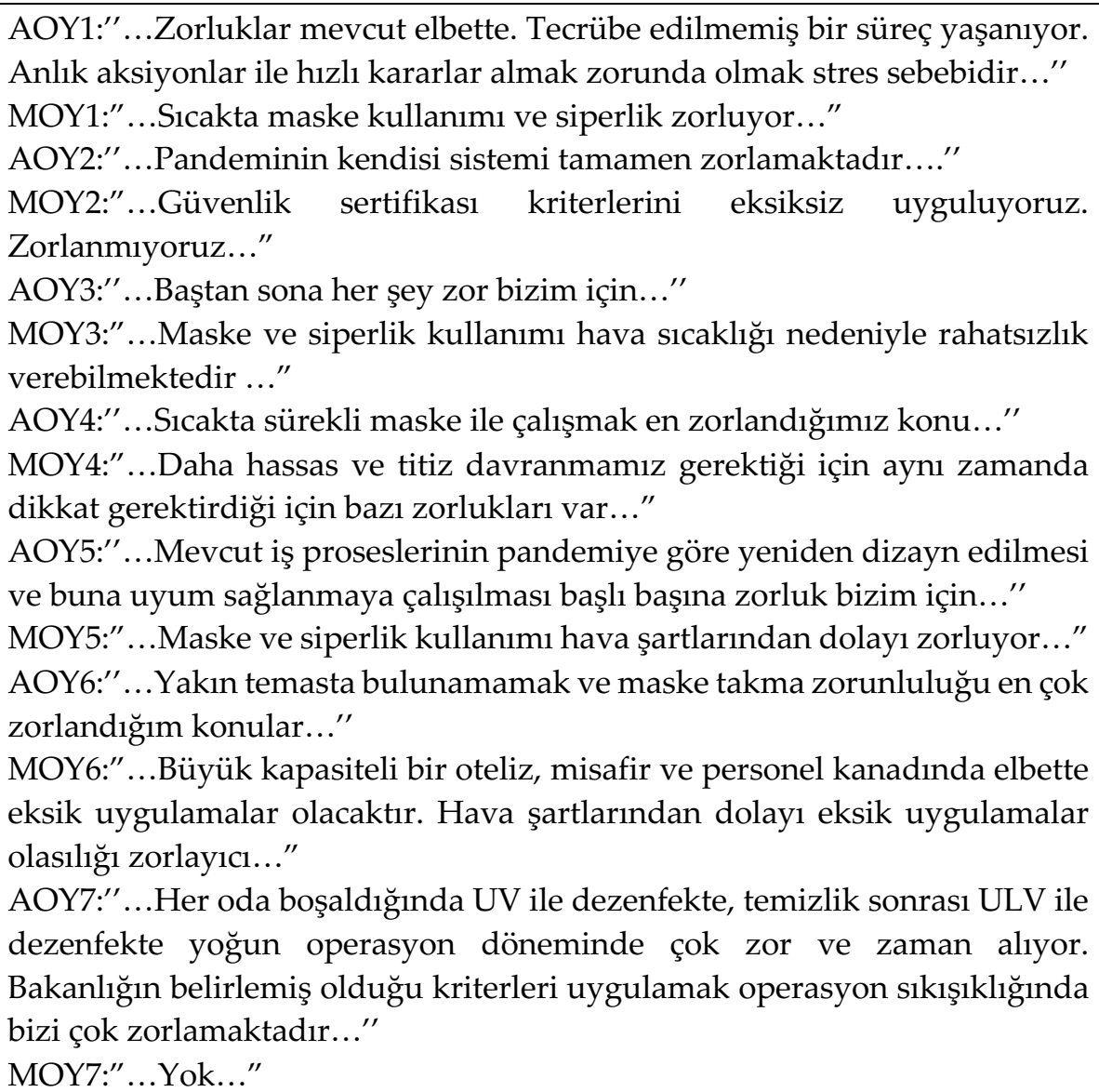 & $\begin{array}{l}\text { İklim } \\
\text { koşullarından } \\
\text { dolayı maske } \\
\text { ve siperlik } \\
\text { kullanımının } \\
\text { zorluğu } \\
\text { (Muğla) } \\
\text { Kriterle } \\
\text { uyum } \\
\text { zorluyor. } \\
\text { İklim } \\
\text { koşulları } \\
\text { zorlayıcıdır. } \\
\text { (Antalya) }\end{array}$ \\
\hline
\end{tabular}

\section{SONUÇ ve ÖNERILER}

Günümüzde dünyanın içinde bulunduğu ekonomik kriz, dünyanın çeşitli bölgelerinde fiili savaş ortamları, değişik bölgelerde olası savaş ortamlarının oluşturduğu gergin ülke ilişkilerinin yarattığ 1 sıkıntılar ve en son olarak Covid-19 pandemisinin oluşturduğu ekonomik yıkım tüm endüstrilerde olduğu gibi turizm endüstrisinde de büyük etki ve yıkımlara yol açmıştır. Doğal olarak tüm ülke halklarının ve ülkelerin varlıklarını sürdürmede turizmden daha çok önem verecekleri ihtiyaçları bulunmaktadır. Ülkeler ve turistlerin ilk tercihlerindeki bu öncelik dururken diş ve iç turizm hareketlerinin pandemi öncesi günlerine dönmesi çok yakın bir ihtimal gibi görülmemektedir. Pandemi, gerek aşı ve gerekse ilaç bulunarak elbette bir gün sonlandırılacaktır. Pandeminin etkilediği endüstri alanlarının toparlanma sürecinin uzaması doğal olarak turizm endüstrisinin de toparlanma süresini etkileyecektir. Turizm endüstrisinin kısıtlamaların azaltılması ve kaldırılması gibi uygulamalar ile toparlanma sürecine girmesine rağmen 2020 yılı için kayıp bir yıl olarak değerlendirilebileceği yapılan araştırma sonuçlarından çıkarılabilir. Tüm bu bilgiler ışı̆̆ında pandemi sürecinde otel işletmelerinde görev alan yöneticiler ile yapılan bu çalışmadan elde edilen bilgilere göre;

Muğla'da faaliyet gösteren otel yöneticilerinin görüşlerine göre yüksek oranda misafirlerin 
uyum gösterdikleri ve kurallara uydukları anlaşılmaktadır. Yöneticilerin ifadelerine göre kural dışı davranış gösteren misafirlerin nazikçe uyarıldı̆̆ 1 , uyarı neticesinde kural dışı davranışın düzeltilip düzeltilmediğinin takip edildiği ve neticede misafirlerin uyarıları dikkate alarak gerekli düzeltmeyi derhal yaptıkları ve sorun yaşamadıkları görülmektedir. Yöneticiler otelde çalışan personelin pandemi kurallarına gereken özen ve dikkati gösterdiği yönünde görüş belirtirken, güvenlik sertifikası alma sürecine hazırlık aşamasının stresli, uzun ve yorucu bir süreç olduğu yönünde düşündüklerini ifade etmektedirler. Otel yöneticileri işletmenin yarı kapasite ile çalışması nedeniyle sosyal mesafe sorunu oluşmadığını fakat işletme tam kapasite çalışmış olsa yiyecek-içecek ve ön büro departmanlarında ihlallerin oluşma ihtimalinin olabileceğini düşünmektedirler. Yöneticilerin tamamı ister istemez ailelerini ve yakın çevrelerini düşünerek insani tedirginliklerinin oluştuğunu fakat iş ortamının yoğunluğunda çoğu zaman bu konuyu unuttuklarını belirtmişlerdir. Otel yöneticileri iklim koşullarında bulundukları mevsim şartlarına göre maske ve siperlik kullanımının olması gereken fakat çok zorlayıcı bir uygulama olduğunu ifade etmişlerdir.

Antalya'da ise yapılan gözlem ve yöneticilerle yapılan görüşmelerin neticesinde, misafirlerin pandemi kurallarına uyum konusunda sıkıntılar dikkat çekmektedir. Otelde nerede ise hiçbir misafirin maske kullanmadığı, özellikle ana restoranda büfe sırasında sosyal mesafenin göz ardı edildiği gözlemlenmiştir. Bunda otelin yanlış büfe dizaynı ve sınırlı sayıda personelle çalışmaları da etken faktörler olarak değerlendirilebilir. Otelin yarı kapasite dolulukla çalışıyor olmasına rağmen böyle bir yoğunluk olumsuz bir ortam oluşturmaktadır. Otel yönetimi Sağlıklı Turizm Sertifikası gereğince tüm tedbirleri almış olmasına rağmen, misafirlerin kurallara uyumu konusunda herhangi bir yaptırım uygulamamaktadır. Hatta uyarı bile yapıldığı gözlemlenmemiştir. Bakanlığın belirlediği tüm kriterlerin sağlanması, birçok alanda el dezenfektanlarının bulunması, uyarıcı levha ve işaretlerle misafirlerin dikkatlerinin çekilmesi, pandemi koşulları altında da tatil yapılabileceğinin göstergesidir. Ancak asıl önemli olan konu, hep personelin hem de misafirlerin bu kurallara harfiyen uyum sağlamasıdır. İşte bu noktada misafir cephesinde problemler olduğu açıktır.

Yapılan araştırma Antalya ve Muğla bölgesindeki iki ayrı otelin karşılaştırılması olanağı vermektedir. Bu doğrultuda Antalya'da misafirlerin pandemi kurallarına uyum konusunda olumsuz bir görüntü çizdiği hem gözlemlerimizden hem de yönetici görüşlerinden anlaşılmaktadır. Muğla'daki otelde ise misafirlerin kurallara uyumu daha yüksek düzeydedir. Buradaki otelin daha geniş bir alana yayılması, misafirlerin kurallar konusunda sık sık uyarılması ve zorunluluk getirmesinin etkili olduğu söylenebilir.

Bu doğrultuda getirilebilecek çözüm önerileri aşağıdaki şekilde sıralanabilir;

- Pandemi konusunda alınan önlemler kâğıt üzerinde kalmamalı, bilakis personelin ve misafirlerin bu kurallara uyumu titizlikle takip edilmelidir.

- Misafirlerin turist kimliği ile alabildiğince özgür olmak istemeleri anlaşılabilir bir durumdur. Ancak covid-19 gerçeği unutulmadan, sosyal mesafe, hijyen ve maske kullanımı konusunda taviz verilmemelidir.

- Otel işletmelerinin bu süreçteki uygulamaları pandemi kurallarına göre revize etmesi kaçınılmazdır.

- Misafirlerin kendilerini rahat ve güvenli bir ortamda hissetmeleri, bazı kuralları göz ardı edebilecekleri anlamına gelmemelidir.

- Otelin her biriminde sağlanacak yeni uygulamalarla hem misafirlere konforlu bir 
konaklama deneyimi sunulmalı, hem de kurallara uyum titizlikle takip edilmelidir.

- Kurallara uyum konusunda en çok sıkıntı yaşanan restoran bölümlerinde yığılmanın önüne geçmek için yeterli sayıda personel istihdam edilmeli, büfe uygulamasının daha alternatifli ve sayısal olarak artırılarak, yemek gruplarına göre bölünerek uzun yemek kuyruklarının önüne geçilmelidir.

- Otelin tüm kapalı alanlarında maske kullanımı zorunlu tutulmalı, maske kullanmayan misafirlerin bu alanlara girişi engellenmelidir.

- Misafirlerin hizmet alımı esnasında tedbirler konusunda nazikçe uyarılması sağlanabilir.

- Böylesine zorlu bir süreçte, otel çalışanlarının fiziksel be ruhsal sağlıkları asla ihmal edilmemeli, bu tür kriz ortamlarında hem kendilerini hem de misafirleri risklerden koruyabilecek bir bilince ve deneyime ulaşmaları sağlanmalıdır.

- Gelecekte karşı karşıya kalınabilecek her türlü kriz için işletmeler bir kriz senaryosuna sahip olmalıdır.

\section{KAYNAKÇA}

Acar, Y., (2020), Yeni Koronavirüs (Covid-19) Salgını ve Turizm faaliyetlerine Etkisi, Güncel Turizm Araştırmaları Dergisi, 4(1): (7-21),

Ahmad, T., Khan, M., Khan, F.M. and Hui, J. (2020). Are we ready for the new fatal Coronavirus: scenario of Pakistan?. Human Vaccines EImmunotherapeutics, 16(3): 736-738

Atay, L. (2020). COVID-19 Salgını ve Turizme Etkileri. Seyahat ve Otel İşletmeciliği Dergisi, 17(1): 168- 172.

Avraham, E. (2016). Destination Marketing and Image Repair During Tourism Crises: The Case of Egypt. Journal of Hospitality and Tourism Management, 28, 41-48.

Bahar, O. ve İlal, N. Ç. (2020). Koronavirüsün Turizm Sektörü Üzerindeki Ekonomik Etkileri. International Journal of Social Sciences and Education Research, 6(1): 125-139.

Bogoch, I. I., Watts, A., Thomas-Bachli, A., Huber, C., Kraemer, M. U. G., and Khan, K. (2020). Potential for global spread of a novel coronavirus from China. Journal of Travel Medicine, 27(2): 1-3

Budak, F. ve Korkmaz, Ş. (2020). Covid-19 Pandemi Sürecine Yönelik Genel Bir Değerlendirme: Türkiye Örneği. Sosyal Araştırmalar ve Yönetim Dergisi, 1: 62-79.

Chiodini, J. (2020). Maps, masks and media-Traveller and practitionerre sources for 2019 novel coronavirus (2019-nCoV) acute respiratory virus. Travel Medicine and Infectious Disease (33): 101574.

Clerkin, J. K., Fried, A. J., Raikhelkar, J., Sayer, G., Grifin, M. J., Masoumi, A., Jain, S. S., Burkhoff, D., Kumaraiah, D., Rabbani, L., Schwartz, A. and Uriel, N. (2020). COVID-19 and Cardiovascular Disease. Circulation. 141,1648-1655.

Columbus, C., Brust, K.B. and Arroliga, A.C. (2020). 2019 Novel coronavirus: an emerging global threat. Baylor University Medical Center Proceedings, 33(2) :1-4.

Cucinotta, D. and Vanelli, M. (2020). WHO Declares COVID-19 a Pandemic. Acta Biomedica, 
91(1): $157-160$

Çobanoğlu, N. (2020). Bireysel, Profesyonel, Toplumsal, Bilimsel ve Siyasal Etiği Yeniden Sorgulatan COVID-19 Pandemisi. Anadolu Kliniği Tıp Bilimleri Dergisi, 25(1): 36-42.

Demir, İ. (2020). Kovid-19 Salgının Seyri ve Türkiye Ekonomisi. Uluslararası İlişkiler ve Stratejik Araştırmalar (ULISA) Enstitüsü, 12(1): 7-16.

Du, Z., Wang, L., Chauchemez, S., Xu, X., Wang, X., Cowling. B, J. and Meyers, L.A. (2020). Risk for transportation of 2019 novel coronavirus disease from Wuhan to other cities in China. Emerg Infect Dis. 26 (5), 1049-1052.

Erol, S. I. (2020). Covid-19'un Çalışma Hayatına Yansımaları Salgından Etkilenen Bazı Ülkeler Tarafından Alınan Önlemler. Dicle Üniversitesi İktisadi ve İdari Bilimler Fakültesi Dergisi, 10(19): 213-232.

Günay, F., Bayraktaroğlu, E. and Özkul, K. (2020). Assessing the Short-term Impacts of COVID-19 Pandemic on Foreign Visitor's Demand for Turkey A Scenario Analysis. Journal of Ekonomi, 4, 80-85.

Işın, B. (2020). Ölçek Ekonomilerinden Kaynak Ekonomilerine Covid-19 Sonrası Konaklama Sektörü Sorunsall, https://www.turizmhabermerkezi.net/haber-olcek-ekonomilerindenkapsam-ekonomilerine-covid-19-sonrasi-konaklama-sektoru-sorunsali-13984.html E.T. 30.06.2020.

Kiper, O. V., Saraç, Ö., Çolak, O. ve Batman, O. (2020), COVID-19 Salgınıyla Oluşan Krizlerin Turizm Faaliyetleri Üzerindeki Etkilerinin Turizm Akademisyenleri Tarafından Değerlendirilmesi, Balıkesir Üniversitesi Sosyal Bilimler Enstitüsü Dergisi. 23(43): 527-551.

Kutlu, R. (2020). Yeni Koronavirüs Pandemisi ile İlgili Öğrendiklerimiz, Tanı ve Tedavisindeki Güncel Yaklaşımlar ve Türkiye'deki Durum. Turkish Journal of Family Medicine and Primary Care, 14(2): 329-344.

Mahase, E. (2020). Coronavirus: global stocks of protective gear are depleted, with demand at "100 times" normal level, WHO warns. Published 10 February 2020). https://www.bmj.com/content/bmj/368/bmj.m543.full.pdf. (Erişim Tarihi: 06.03.2020).

Patton, M.Q. (1987). How to use qualitative methods in evaluation. Newbury Park, CA: Sage Publications.

Quilty, B. J., Clifford, S., Flasche, S., and Eggo, R. M. (2020). Effectiveness of airport screening at detecting travellers infected with novel coronavirus (2019-nCoV). Euro Surveill. 25(5), 3658.

Rodriguez-Morales, AJ., Gallego, V., Escalera-Antezana, JP., Mendez, CA., Zambrano, LI., Franco-Paredes, C., Suárez, JA., Rodriguez-Enciso, HD., Balbin-Ramon, GJ., Savio-Larriera, E., Risquez, A., and Cimerman, S. (2020). COVID19 in Latin America: The implications of the first confirmed case in Brazil. Travel Med Infect Dis. 29,1-11.

Strielkowski, W. (2020). International Tourism and Covid-19 Recovery Strategies for Tourism Organisations. https://www.preprints.org/manıscript/202003.0445/v1, Preprints: 16, Erişim tarihi: 15.07. 2020.

Wilson, M.E. and Chen, L. H. (2020). Travellers give wings to novel coronavirus (2019-nCoV). Journal of Travel Medicine. (1-3). https://doi.org/10.1093/jtm/taaa015. (Erişim Tarihi: 15.07.2020).

Zi Yue Zu, Meng Di Jiang, Peng Peng Xu, Wen Chen, Qian Qian Ni, Guang Ming Lu, Long 
and Jiang Zhang, (2020). Coronavirus Disease 2019 (COVID-19): A Perspective from China, Radiology RSNA, 296: 115-125.

Zheng, Y.Y., Ma, T. Y., Zhang, Y. J. and Xie, X. (2020), COVID-19 and the cardiovascular system, Nature Reviews Cardiology, 17: 259-260.

Yıldırım, A. ve Şimşek, H. (2013). Sosyal Bilimlerde Nitel Araştırma Yöntemleri, 9. Baskı, Seçkin Yayıncılık, Ankara. 